\title{
Association between pesticide and polychlorinated biphenyl exposure during pregnancy and autism spectrum disorder among children: a meta-analysis
}

\author{
Fereshteh Mehri, PhD, Saeid Bashirian, $\mathrm{PhD}^{2}$, Salman Khazaei, $\mathrm{PhD}^{3}$, Ensiyeh Jenabi, $\mathrm{PhD}^{4}$
}

${ }^{1}$ Nutrition Health Research Center, Hamadan University of Medical Sciences, Hamadan, Iran; ${ }^{2}$ Social Determinants of Health Research Center, Hamadan University of Medical Sciences, Hamadan, Iran; ${ }^{3}$ Department of Epidemiology, Hamadan University of Medical Sciences, Hamadan, Iran; ${ }^{4}$ Autism Spectrum Disorders Research Center, Hamadan University of Medical Sciences, Hamadan, Iran

Background: The effect of exposure to environmental factors on autism spectrum disorders (ASD), especially during pregnancy, is unclear.

Purpose: This meta-analysis investigated the association between exposure to pesticides and polychlorinated biphenyls (PCBs) during pregnancy and ASD risk among children.

Methods: We searched Scopus, PubMed, Web of Science, and ProQuest for articles published through September 2019. Random-effects models were used to examine the association among studies using pooled odds ratios (ORs) and their 95\% confidence intervals (CI). I2 tests were used to measure interstudy heterogeneity.

Results: The pooled OR indicated a significant association between $\mathrm{PCB}$ and pesticide exposure during pregnancy and ASD risk among children (OR, 1.80; 95\% CI, 1.26-2.34; and OR, 1.20; 95\% CI, 1.02-1.39), respectively.

Conclusion: Findings of the present study indicate that exposure to pesticides and PCBs during pregnancy may affect the risk of ASD among children.

Key words: Autism spectrum disorders, Autism, Metaanalysis, Polychlorinated biphenyls, Pesticides

\section{Key message}

This meta-analysis analyzed the association between pesticide and polychlorinated biphenyl (PCB) exposure during pregnancy and autism spectrum disorders (ASD) risk among children.

- A significant association was noted between PCB and pesticide exposure during pregnancy and ASD risk among children (odds ratio [OR], 1.80; 95\% confidence interval [CI], 1.262.34 and OR, $1.20 ; 95 \%$ CI, 1.02-1.39), respectively.

Pesticide and PCB exposure during pregnancy may affect ASD risk among children.

\section{Introduction}

Autism spectrum disorders (ASDs) are a group of neurodevelopment disorders affecting approximately $1.5 \%$ of children in most societies. ${ }^{1)}$ The range and severity of related symptoms among children are restricted. These symptoms include repetitive patterns of behavior, difficulty with verbal and nonverbal communication, and atypical socialization. ${ }^{2)}$ An increasing pattern in the incidence of ASDs has been indicated over the last 20 years. ${ }^{3)}$ The etiology of this disease is unclear, and although many studies have reported that genetic factors play a role, they fail to provide explanation for all cases. ${ }^{4)}$ Preeclampsia, low birth weight, and neonatal icterus are risk factors for ASD. ${ }^{5,6}$ It was recently reported that exposure to environmental chemicals during pregnancy may play an important role in the early development of ASDs. ${ }^{7,8)}$

Polychlorinated biphenyls (PCB) are a class of persistent organic pollutions in the environment with neurotoxic properties.9) The possible mechanisms induced by PCB in the etiology of ASD include effects on neuronal development, oxidative stress, neuroexcitability, and disturbance of steroid hormone levels. ${ }^{10)}$ Many studies have investigated the impact of prenatal PCB exposure and neurodevelopmental disorders in children. ${ }^{11-13)}$ Pesticides are a class of chemical compounds, including insecticides, herbicides, fungicides, and rodenticides, that are widely used throughout the world. The toxicity mechanisms of pesticides are diverse. The changes in neuroprotein levels, gene expressions, and neurobehavioral abnormalities have been broadly reported in different studies. ${ }^{14)}$ Gunier et al., ${ }^{15)}$ Horton et al., ${ }^{16)}$ Rauh et al., ${ }^{17)}$ and Grandjean and Landrigan ${ }^{18}$ have shown that prenatal exposure to several types of pesticides is associated with neurodevelopmental disorders and ASDs. Few studies have demonstrated no association between pesticide exposure during pregnancy and ASDs among children. Exposure to pesticides and PCBs during pregnancy is a risk factor for ASD development among children; to date, no meta-analysis has been performed

Corresponding author: Ensiyeh Jenabi, PhD, Autism Spectrum disorders Research Center, Hamadan University of Medical Sciences, Hamadan, Iran 凶 Email: en.jenabi@yahoo.com, https://orcid.org/0000-0002-4536-0814

Received: 10 May, 2020, Revised: 16 July, 2020, Accepted: 25 July, 2020

This is an open-access article distributed under the terms of the Creative Commons Attribution Non-Commercial License (http://creativecommons.org/licenses/bync/4.0/) which permits unrestricted non-commercial use, distribution, and reproduction in any medium, provided the original work is properly cited.

Copyright (c) 2021 by The Korean Pediatric Society 


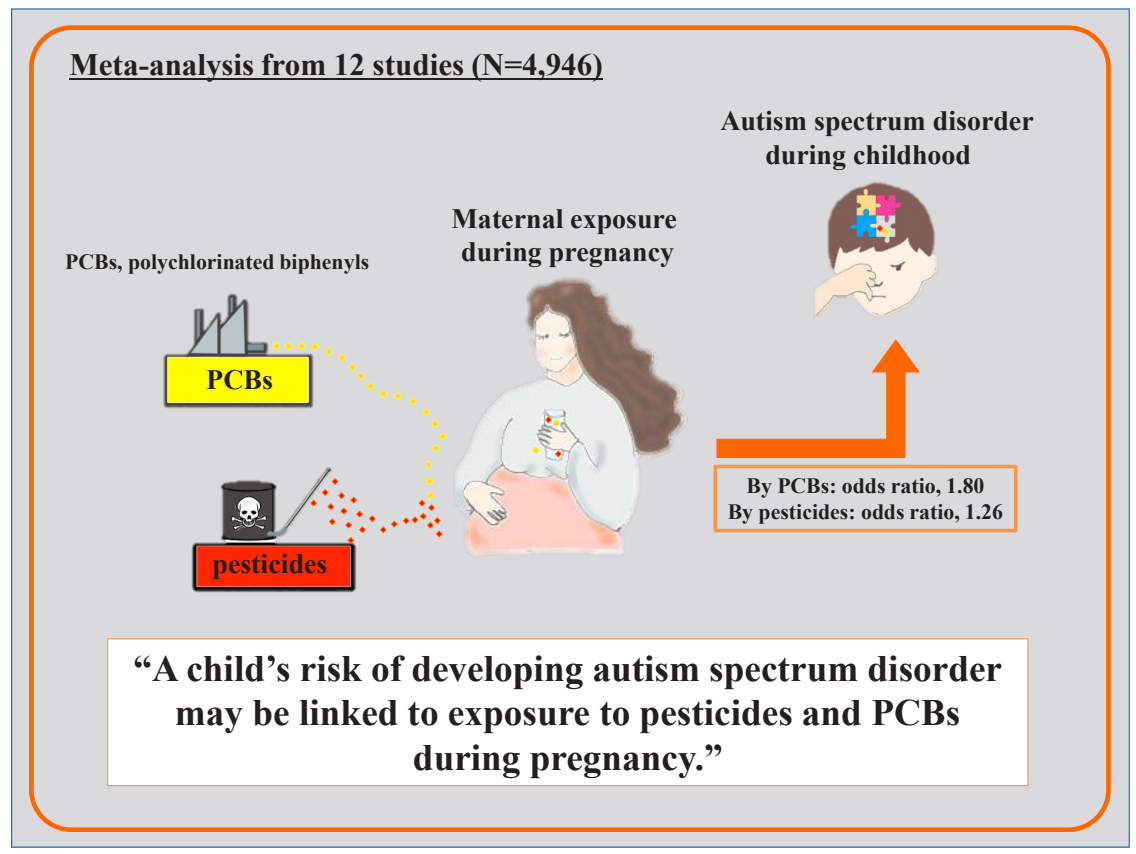

Graphical abstract.

on this aspect. Therefore, this is the first meta-analysis to pool all case-control and cohort studies extracted from broader databases to examine the association between pesticide and PCB exposure during pregnancy and the risk of ASDs among children.

\section{Methods}

\section{Data}

The major international databases (PubMed, Scopus, ProQuest, and Web of Science) were reviewed for relevant articles published through September 2019 using the following keywords: (pesticides OR DMTP OR dimethyl thiophosphate) AND (PCB OR polychlorinated biphenyls) AND (autism OR ASD OR autism spectrum disorder) with no restrictions on language or time. The reference lists of the retrieved studies were manually searched to identify additional articles.

\section{Eligibility criteria}

Studies were considered eligible for inclusion if they met the following criteria: cohort, case-control, or cross-sectional study design; exposure of interest was pesticides and PCB; and outcome of interest was ASD. We excluded letters to the editor, comments, reviews, and case reports.

\section{Data extraction and quality assessment}

Information recorded in the data sheet included the following details: first author name, year of publication, country of origin, sample size, diagnostic method, estimates (relative risk [RR], odds ratio [OR]) and their associated 95\% confidence intervals (CIs), statistical adjustment for confounding factors (crude/ adjusted), child's age (mean or range), and study quality. Two independent authors (FM and EJ) assessed the studies and extracted the relevant data. In this process, any disagreements were resolved by discussion.

Study quality was assessed by checking the selection, comparability, exposure, and outcome using the Newcastle Ottawa Statement Manual (NOS) instrument. ${ }^{19)}$ According to the aforementioned items, there was a maximum of 9 devoted stars for each study. The studies with 7 or more star items were categorized as high quality, while the others were considered low-quality.

\section{Statistical analysis}

The OR was used to measure the association between pesticide and $\mathrm{PCB}$ exposure during pregnancy and ASDs among children. The combined OR and corresponding 95\% CI were calculated using random-effects models. The meta-analysis was performed based on crude and adjusted form to control for confounding variables. The homogeneity of effect size was tested using the $Q$ statistic, while the $I^{2}$ statistic was used to measure interstudy heterogeneity. A funnel plot and Begg test were employed to assess possible publication bias. The data were analyzed using Stata software version 14 (StataCorp, College Station, TX, USA). Significance level was set at 0.05 .

We conducted the study according to the Preferred Reporting Items for Systematic reviews and Meta-Analysis guidelines. ${ }^{20)}$

\section{Results}

A total of 754 papers published through September 2019 were identified through advanced searches of the above-mentioned electronic databases and manual reference list searches. Of these papers, 274 were excluded for being duplicates. In the 


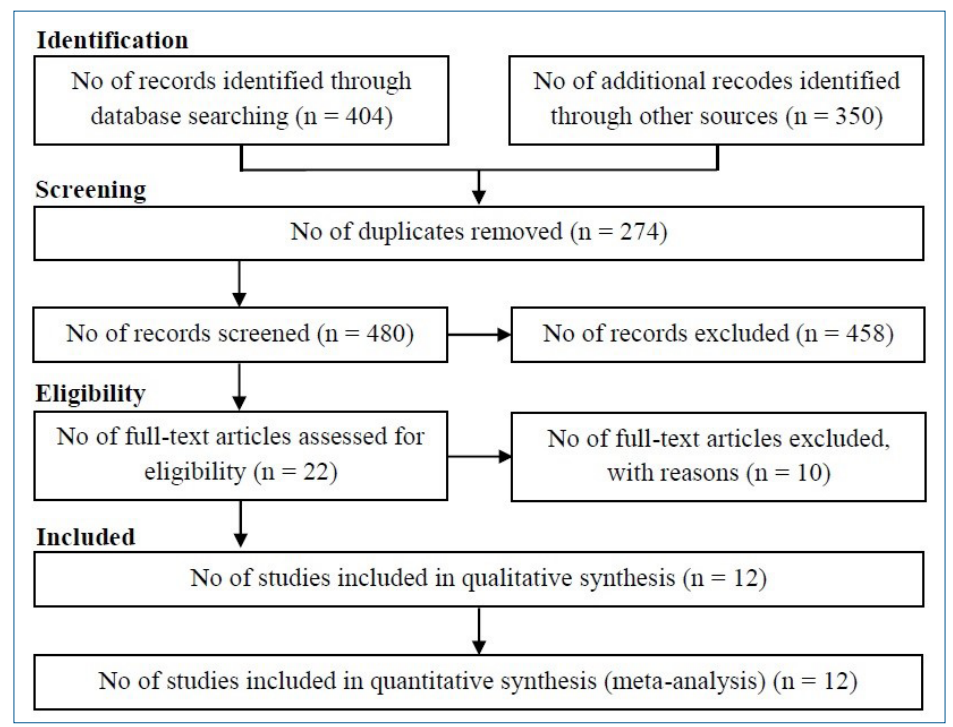

Fig. 1. Diagram of studies through the different phases of the meta-analysis.

\begin{tabular}{|c|c|c|c|}
\hline Study & & & $\%$ \\
\hline ID & & OR $(95 \% \mathrm{Cl})$ & Weight \\
\hline Bernardo, 2019 & & $1.80(1.00,2.90)$ & 32.78 \\
\hline Cheslack-Postava, 2013 & & $1.91(0.57,6.39)$ & 3.49 \\
\hline Granillo, 2019 & & $2.63(0.87,7.97)$ & 2.35 \\
\hline Lyall, 2017 & & $1.82(1.10,3.02)$ & 32.10 \\
\hline Mitchell, 2012 & $\rightarrow$ & $1.70(0.99,3.00)$ & 29.29 \\
\hline Overall (I-squared $=0.0 \%, P=0.993$ ) & & $1.80(1.26,2.34)$ & 100.00 \\
\hline NOTE: Weights are from random effects analysis & & & \\
\hline
\end{tabular}

Fig. 2. Forest plot of the association between polychlorinated biphenyls exposure during pregnancy and autism spectrum disorders among children. OR, odds ratio; $\mathrm{Cl}$, confidence interval.

title and abstract assessment, 458 studies were excluded due to not meeting the selection criteria. In the full-text assessment, 10 were excluded. Therefore, a total of 12 studies were included in the present meta-analysis. Of them, one was cross-sectional, ${ }^{21)}$ 7 were case-control, ${ }^{22-28)}$ and 4 were cohort ${ }^{29-32)}$ (Fig. 1). The articles were published in English between 2007 and 2019 and included a total number of 4,946 participants.

\section{Effects of exposure}

Fig. 2 presents the association between $\mathrm{PCB}$ exposure during pregnancy and ASD among children. Based on OR estimates obtained from the studies, there was a significant correlation between PCB exposure during pregnancy and ASDs among children (OR, 1.80; 95\% CI, 1.26-2.34). The results were homogenous $\left(I^{2}=0 \%, P=0.993\right)$. Table 1 shows the results of the subgroup analysis of PCB types and ASDs. Based on OR
Table 1. Results of subgroup analysis of types of PCBs and Autism spectrum disorders

\begin{tabular}{lccr}
\hline & \multicolumn{3}{c}{ Studies } \\
\cline { 2 - 3 } Subgroups & $\begin{array}{c}\text { No. of } \\
\text { studies }\end{array}$ & OR (95\% Cl) & \multicolumn{2}{c}{} \\
\hline Types of PCBs (studies based on OR) & & & \\
PCB118 & 4 & $1.09(0.74-1.44)$ & $0 \%$ \\
PCB138 & 3 & $1.79(1.14-2.44)$ & $0 \%$ \\
PCB153 & 4 & $1.32(0.82-1.82)$ & $40.1 \%$ \\
PCB170 & 3 & $1.45(0.93-1.97)$ & $0 \%$ \\
PCB180 & 4 & $1.35(0.88-1.83)$ & $0 \%$ \\
\hline
\end{tabular}

$\mathrm{PCB}$, polychlorinated biphenyls; OR, odds ratio; $\mathrm{Cl}$, confidence interval.

estimates obtained from the studies, there was a significant correlation between PCB138 exposure during pregnancy and ASDs among children (OR, 1.79; 95\% CI, 1.14-2.44). There 


\begin{tabular}{|c|c|c|c|}
\hline \multicolumn{3}{|l|}{ Study } & $\%$ \\
\hline \multicolumn{2}{|l|}{ ID } & $\mathrm{OR}(95 \% \mathrm{Cl})$ & Weight \\
\hline Brown, 2018 & $\rightarrow$ & $2.21(1.32,3.69)$ & 2.32 \\
\hline Cheslack-Postava, 2013 & & $1.79(0.52,6.21)$ & 0.42 \\
\hline Christian, 2018 & $\rightarrow$ & $1.67(1.08,2.59)$ & 5.33 \\
\hline Von Ehrenstein, 2019 & - & $1.13(1.05,1.23)$ & 41.89 \\
\hline Hicks, 2017 & 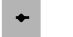 & $1.37(1.06,1.78)$ & 16.87 \\
\hline Keil, 2016 & $\rightarrow$ & $1.30(0.79,2.20)$ & 6.01 \\
\hline Philippat, 2018 & - & $0.99(0.79,1.25)$ & 27.08 \\
\hline Roberts, 2007 & : & $6.10(2.40,15.30)$ & 0.08 \\
\hline Overall (I-squared $=36.0 \%, P=0.141$ ) & $\theta$ & $1.20(1.02,1.39)$ & 100.00 \\
\hline NOTE: Weights are from random effects analysis & i & & \\
\hline & 12 & & \\
\hline
\end{tabular}

Fig. 3. Forest plot of the association between pesticide exposure during pregnancy and autism spectrum disorders among children. OR, odds ratio; $\mathrm{Cl}$, confidence interval.

Table 2. Summaries of included PCBs studies in present meta-analysis

\begin{tabular}{|c|c|c|c|c|c|c|c|c|c|c|c|c|}
\hline Study & Country & Design & $\begin{array}{l}\text { Sample } \\
\text { size (n) }\end{array}$ & Method & Unit & Estimate & $\begin{array}{l}\text { Adjust- } \\
\text { ment }\end{array}$ & $\begin{array}{l}\text { OR/RR } \\
\text { Total }\end{array}$ & Kind & $\begin{array}{l}\text { Autism } \\
\text { criteria }\end{array}$ & $\begin{array}{l}\text { Child age } \\
\text { range (yr) }\end{array}$ & Quality \\
\hline $\begin{array}{l}\text { Bernardo, } \\
2019 \\
29)\end{array}$ & Canada & Cohort & 546 & GC-MASS & $\mathrm{ng} / \mathrm{g}$ & $\begin{array}{l}\text { Odds } \\
\text { ratio }\end{array}$ & Crude & $\begin{array}{c}1.8 \\
(1.0-2.9)\end{array}$ & $\begin{array}{l}\text { PCB118; } 1.20(0.72-1.89) \\
\text { PCB138; } 1.76(0.99-2.92) \\
\text { PCB153; } 1.82(1.02-3.02) \\
\text { PCB170; } 1.39(0.80-2.24) \\
\text { PCB180; } 1.20(0.67-1.98)\end{array}$ & SRS-2 & $3-4$ & High \\
\hline $\begin{array}{l}\text { Cheslack- } \\
\text { Postava, } \\
2013\end{array}$ & Finland & $\begin{array}{l}\text { Case- } \\
\text { control }\end{array}$ & 150 & GC-MASS & $\mathrm{ng} / \mathrm{g}$ & $\begin{array}{l}\text { Odds } \\
\text { ratio }\end{array}$ & Adjusted & $\begin{array}{c}1.91 \\
(0.57-6.39)\end{array}$ & $\begin{array}{l}\text { PCB118; } 1.00(0.32-3.10) \\
\text { PCB138; } 2.25(0.69-7.31) \\
\text { PCB153; } 1.80(0.60-5.37) \\
\text { PCB170; } 1.67(0.61-4.59) \\
\text { PCB180; } 1.83(0.68-4.96)\end{array}$ & ICD-10 & $38-40$ & High \\
\hline $\begin{array}{l}\text { Granillo, } \\
2019\end{array}$ & USA & Cohort & 104 & $\begin{array}{c}\text { GC-MS/ } \\
\text { MS }\end{array}$ & $\mathrm{ng} / \mathrm{mL}$ & $\begin{array}{l}\text { Odds } \\
\text { ratio }\end{array}$ & Adjusted & $\begin{array}{c}2.63 \\
(0.87-7.97)\end{array}$ & $\begin{array}{l}\text { PCB118; } 0.74 \text { (0.28 to } 1.96) \\
\text { PCB153; } 0.67(0.26 \text { to } 1.77) \\
\text { PCB180; } 1.46 \text { (0.55 to } 3.87)\end{array}$ & ADOS & 3 & High \\
\hline $\begin{array}{l}\text { Lyall, } \\
2017 \\
2017\end{array}$ & USA & $\begin{array}{l}\text { Case- }^{-} \\
\text {control }\end{array}$ & 872 & $\begin{array}{c}\text { GC- } \\
\text { IDHRMS }\end{array}$ & $\mathrm{ng} / \mathrm{g}$ & $\begin{array}{l}\text { Odds } \\
\text { ratio }\end{array}$ & Adjusted & $\begin{array}{c}1.82 \\
(1.10-3.02)\end{array}$ & $\begin{array}{l}\text { PCB118; } 1.15(0.72-1.82) \\
\text { PCB138; } 1.79(1.10-2.92) \\
\text { PCB153; } 1.82(1.10-3.02) \\
\text { PCB170; } 1.48(0.88-2.50) \\
\text { PCB180; } 1.49(0.89-2.49)\end{array}$ & DSM-IV & $\begin{array}{c}\text { No } \\
\text { reported }\end{array}$ & High \\
\hline $\begin{array}{l}\text { Mitchell, }{ }^{26)} \\
2012\end{array}$ & USA & $\begin{array}{l}\text { Case- }^{-} \\
\text {control }\end{array}$ & 107 & $\mathrm{GC} / \mathrm{MS}$ & $\mathrm{ng} / \mathrm{g}$ & $\begin{array}{l}\text { Odds } \\
\text { ratio }\end{array}$ & Adjusted & $\begin{array}{c}1.7 \\
(0.99-3.0)\end{array}$ & - & Clinical & $\begin{array}{c}\text { No } \\
\text { reported }\end{array}$ & High \\
\hline
\end{tabular}

OR, odds ratio; RR, relative risk; GC-MASS, Gas chromatography-mass spectrometry; GC-MS/MS, Gas chromatography-mass spectrometry (GC-MS); SRS-2, social responsiveness scale (Second Edition); ADOS, Autism Diagnostic Observation Schedule; DSM-IV, Diagnostic and Statistical Manual ; PCB, polychlorinated biphenyls; ICD-10, International Statistical Classification of Diseases, 10th revision; GC-IDHRMS, gas chromatography-isotope dilution high resolution mass spectrometry.

was no significant correlation between PCB118, PCB153, PCB170, and PCB180 and ASDs among children.

Also, based on the OR estimates obtained from the studies, there was a statistically significant relationship between pesticide exposure during pregnancy and ASDs among children (OR, $1.20 ; 95 \% \mathrm{CI}, 1.02-1.39)$. There was mild heterogeneity among the results $\left(I^{2}=36.0 \%, P=0.141\right)$ (Fig. 3$)$.

Among the included studies, one study ${ }^{21)}$ reported the results based on RR. In the same study, there was a significant relationship between pesticide exposure during pregnancy and ASDs among children (OR, 1.37; 95\% CI, 1.06-1.78). Cheslack-
Postava et al. ${ }^{22)}$ simultaneously assessed the association between exposure to pesticides and PCB during pregnancy and ASDs among children. According to the methodology of this study, the total of 150 patients (75 subjects with autism and 75 controls) were selected and both compounds (pesticides and PCBs) were evaluated using blood sample of these patients.

\section{Publication bias}

Begg and Egger tests were applied to assess publication bias among studies of pesticide and PCB exposure. No publication bias among studies was detected on either test in terms of 
Table 3. Summaries of included pesticides studies in present meta-analysis

\begin{tabular}{|c|c|c|c|c|c|c|c|c|c|c|c|c|c|}
\hline Study & Country & Design & $\begin{array}{l}\text { Sample } \\
\text { size (n) }\end{array}$ & Method & $\begin{array}{l}\text { Organic } \\
\text { pollutant }\end{array}$ & Kind & Unit & $\begin{array}{l}\text { Esti- } \\
\text { mate }\end{array}$ & $\begin{array}{l}\text { Adjust- } \\
\text { ment }\end{array}$ & $\begin{array}{l}\text { OR/RR } \\
\text { Total }\end{array}$ & $\begin{array}{l}\text { Autism } \\
\text { criteria }\end{array}$ & $\begin{array}{l}\text { Child age } \\
\text { range (yr) }\end{array}$ & Quality \\
\hline $\begin{array}{l}\text { Philippat, } \\
2018\end{array}$ & USA & Cohort & 203 & $\begin{array}{l}\text { LC-mass/ } \\
\text { mass }\end{array}$ & $\begin{array}{l}\text { Pesticides } \\
\text { insecticide }\end{array}$ & Organophosphat & $\mathrm{ng} / \mathrm{g}$ & $\begin{array}{l}\text { Odds } \\
\text { ratio }\end{array}$ & Adjusted & $\begin{array}{c}0.99(0.79- \\
1.25)\end{array}$ & ADOS & 3 & High \\
\hline $\begin{array}{l}\text { Roberts, }{ }^{27)} \\
2007\end{array}$ & USA & $\begin{array}{l}\text { Case- } \\
\text { control }\end{array}$ & 465 & Pyrethroid & $\begin{array}{l}\text { Pesticides } \\
\text { insecticide }\end{array}$ & Organochlorine & NM & $\begin{array}{l}\text { Odds } \\
\text { ratio }\end{array}$ & Crude & $\begin{array}{c}6.1 \\
(2.4-15.3)\end{array}$ & Clinical & $\begin{array}{l}\text { No } \\
\text { reported }\end{array}$ & High \\
\hline $\begin{array}{l}\text { Brown, } \\
2018\end{array}$ & Finland & Cohort & 778 & GC-MASS & $\begin{array}{l}\text { Pesticides } \\
\text { insecticide }\end{array}$ & Organochlorine & $\mathrm{ng} / \mathrm{g}$ & $\begin{array}{l}\text { Odds } \\
\text { ratio }\end{array}$ & Adjusted & $\begin{array}{c}2.21 \\
(1.32- \\
3.69)\end{array}$ & ICD-10 & $\begin{array}{l}\text { No } \\
\text { reported }\end{array}$ & High \\
\hline $\begin{array}{l}\text { Cheslack- } \\
\text { Postava, } \\
2013\end{array}$ & Finland & $\begin{array}{l}\text { Case- } \\
\text { control }\end{array}$ & 150 & GC-MASS & $\begin{array}{l}\text { Pesticides } \\
\text { insecticide }\end{array}$ & Organochlorine & $\mathrm{ng} / \mathrm{g}$ & $\begin{array}{l}\text { Odds } \\
\text { ratio }\end{array}$ & Adjusted & $\begin{array}{c}1.79 \\
(0.52- \\
6.21)\end{array}$ & ICD-10 & $\begin{array}{l}\text { No } \\
\text { reported }\end{array}$ & High \\
\hline $\begin{array}{l}\text { Christian, } \\
2018\end{array}$ & Jamaica & $\begin{array}{l}\text { Case- } \\
\text { control }\end{array}$ & 298 & NM & $\begin{array}{l}\text { Pesticides } \\
\text { insecticide }\end{array}$ & $\begin{array}{l}\text { Organochlorines } \\
\text { Organophosphat }\end{array}$ & NM & $\begin{array}{l}\text { Odds } \\
\text { ratio }\end{array}$ & Adjusted & $\begin{array}{c}1.67 \\
(1.08- \\
2.59)\end{array}$ & $\begin{array}{l}\text { CARS; } \\
\text { DSM }\end{array}$ & $2-8$ & High \\
\hline $\begin{array}{l}\text { Von } \\
\text { Ehrenstein, }{ }^{28)} \\
2019\end{array}$ & USA & $\begin{array}{l}\text { Case- } \\
\text { control }\end{array}$ & 445 & pyrethroid & $\begin{array}{l}\text { Pesticides } \\
\text { insecticide }\end{array}$ & Organophosphate & NM & $\begin{array}{l}\text { Odds } \\
\text { ratio }\end{array}$ & Adjusted & $\begin{array}{c}1.13 \\
(1.05- \\
1.23)\end{array}$ & $\begin{array}{l}\text { DSM-IV } \\
\text { ICD-9 }\end{array}$ & 4-11 & High \\
\hline $\begin{array}{l}\text { Hicks, }{ }^{21)} \\
2017\end{array}$ & USA & $\begin{array}{l}\text { Cross- } \\
\text { sectional }\end{array}$ & 159 & NM & $\begin{array}{l}\text { Pesticides } \\
\text { insecticide }\end{array}$ & Pyrethroid & NM & $\begin{array}{l}\text { Rate } \\
\text { ratio }\end{array}$ & Adjusted & $\begin{array}{c}1.37 \\
(1.06- \\
1.78)\end{array}$ & ICD-9 & $<20$ & High \\
\hline $\begin{array}{l}\text { Keil, }_{1}^{24)} \\
2016\end{array}$ & USA & $\begin{array}{l}\text { Case- } \\
\text { control }\end{array}$ & 669 & NM & $\begin{array}{l}\text { Pesticides } \\
\text { insecticide }\end{array}$ & Neonicotinoids & NM & $\begin{array}{l}\text { Odds } \\
\text { ratio }\end{array}$ & Adjusted & $\begin{array}{c}1.3 \\
(0.79-2.2)\end{array}$ & Clinical & $3-10$ & High \\
\hline
\end{tabular}

OR, odds ratio; RR, relative risk; ADOS, Autism Diagnostic Observation Schedule; GC-MASS, Gas chromatography-mass spectrometry; ICD-10, International Statistical Classification of Diseases, 10th revision; GC-IDHRMS, gas chromatography-isotope dilution high resolution mass spectrometry; LC-mass/mass, high-performance liquid chromatography coupled with tandem mass spectrometry; NM, not mentioned; CARS, The childhood autism rating scale; DSM-IV, Diagnostic and Statistical Manual.

pesticide exposure $(P=0.608$ and $P=0.503$, respectively $)$ or PCB exposure $(P=0.624$ and $P=0.172$, respectively) for ASDs among children.

\section{Study quality}

Based on NOS scale assessment, 12 studies were of high quality (Tables 2,3).

\section{Discussion}

To the best of our knowledge, this systematic review and meta-analysis is the first investigation of the association between pesticide and $\mathrm{PCB}$ exposure during pregnancy and ASD risk among children. We evaluated the association between pesticide and $\mathrm{PCB}$ exposure during pregnancy and the risk of developing ASDs among different children according to available evidence from case-control and cohort epidemiological studies. The results of the present study indicate the significance of the association between pesticide and PCB exposure during pregnancy and the risk of ASDs among children.

Persistent organic pollutants are known to cause neurological diseases in humans. Once absorbed, these pollutants can remain in the body's adipose tissue for up to 30 years. ${ }^{33)}$ PCBs are a class of persistent organic chemicals with lipophilic properties. ${ }^{9}$ The possible mechanisms of PCBs in the etiology of ASDs include effects on neuronal development, the production of oxidative stress, neuroexcitability, and disturbed steroid hormone levels. ${ }^{10,11)}$ Kim et al. ${ }^{34)}$ and Lee et al. ${ }^{35)}$ have suggested that DNA methylation within neurons influences both singlecarbon metabolism and the glutathione synthesis pathway via environmental exposure to PCBs, which alters cortical networks, long-term potentiation, and hippocampal connectivity.

Many studies have investigated the effect of prenatal exposure to PCBs and neurodevelopment disorders in children. The current study was established based on the existing literature. 11,13,36) A case-control study by Cheslack-Postava et al. ${ }^{22}$ reported much evidence related to high PCB levels and the risk of ASD development among children aged 3-5 years. A birth cohort study by Bernardo et al. ${ }^{29}$ showed a significant association between several PCBs and more autistic behavior. A case-control study by Lyall et al. ${ }^{25}$ ) of a California population indicated clearer evidence of dose-response relationships between $\mathrm{PCB}$ exposure during pregnancy and the risk of ASD in the newborn. However, the effects of low-level PCB exposure on ASD remains unclear. In the current study, to assess PCB exposure during pregnancy and ASD risk among children, the association between pesticide exposure during pregnancy and ASD risk among children was evaluated. According to our findings, reports of the pooled estimate and heterogeneity regarding pesticide exposure indicated mild heterogeneity (OR, 1.20; 95\% CI, 1-1.02). Therefore, there was a significant association between pesticide exposure during pregnancy and the risk of ASDs among children.

Pesticides are a class of chemical compounds that include various groups. The toxicity mechanisms of pesticides depend- 
ing on the chemical structure are diverse. Insecticides are the most important group of pesticides. The main mechanism of insecticides is the inhibition of acetylcholine in the nervous system, which leads to their accumulation in the neuronal junction. ${ }^{37)}$ The changes in the signaling pathway of neurotransmitters, gene expression, abnormal thyroid hormone levels, and mitochondrial dysfunction have been widely investigated in many studies. ${ }^{14,38)}$ However, the possible mechanisms of pesticides and PCBs differ among individuals and depend on the interaction between environmental and genetic factors. Several epidemiologic studies have indicated that pesticide exposure is a potential risk factor for ASD. Based on previous studies, Sagiv et al. ${ }^{39}$ illustrated a positive association between prenatal exposure to organophosphate pesticides and behavior like ASD among children. Considering the results obtained from many animal studies, a fetus is highly susceptible to pesticides, which can cross the placenta and affect the metabolic pathways required for their processing and excretion. Hence, prenatal exposure to pesticides can interfere with neurodevelopment ${ }^{40)}$ and motor development, ${ }^{38)}$ induce oxidative stress, and lead to autismlike behavioral abnormalities. ${ }^{41,42)}$ Some researchers assessed exposure to different pesticides using maternal biological markers and reported an association between pesticides and $\mathrm{ASD}^{32)}$ or autistic behaviors. ${ }^{27)}$ Therefore, the results of previous studies and the present meta-analysis suggest that exposure to pesticides and $\mathrm{PCBs}$ during pregnancy may be a risk factor for ASD.

The present meta-analysis had 3 limitations. First, confounding factors were not controlled for all studies. Two studies reported a crude estimate of the confounder variables. Second, the data presented by the included studies were insufficient to allow a subgroup analysis. Third, the applied diagnostic criteria for ASD varied such that some studies did not use standardized diagnostic instruments for ASD. These limitations might have created selection bias. Despite these limitations, this metaanalysis evaluated the association between pesticide and PCB exposure during pregnancy and ASD risk among children based on epidemiological studies. Therefore, ASD risk among children may be linked to pesticide and PCB exposure during pregnancy.

In conclusion, despite the existing controversy, our findings indicate that ASD risk and development may be linked to pesticide and $\mathrm{PCB}$ exposure during pregnancy.

\section{Conflicts of interest}

No potential conflict of interest relevant to this article was reported.

\section{References}

1. Newschaffer CJ, Croen LA, Daniels J, Giarelli E, Grether JK, Levy SE, et al. The epidemiology of autism spectrum disorders. Annu Rev Public Health 2007;28:235-58.

2. Stein TP, Schluter MD, Steer RA, Guo L, Ming X. Bisphenol A exposure in children with autism spectrum disorders. Autism Res 2015;8:272-83.
3. Weintraub K. The prevalence puzzle: autism counts. Nature News 2011; 479:22-4.

4. Hallmayer J, Cleveland S, Torres A, Phillips J, Cohen B, Torigoe T, et al. Genetic heritability and shared environmental factors among twin pairs with autism. Arch Gen Psychiatry 2011;68:1095-102.

5. Jenabi E, Afshari M, Khazaei S. The association between preeclampsia and the risk of metabolic syndrome after delivery: a meta-analysis. J Matern Fetal Neonatal Med 2019:1-6.

6. Jenabi E, Bashirian S, Khazaei S. The association between neonatal Jaundice and autism spectrum disorders among children: a meta-analysis. Clin Exp Pediatr 2020:63:8-13.

7. Kalkbrenner AE, Schmidt RJ, Penlesky AC. Environmental chemical exposures and autism spectrum disorders: a review of the epidemiological evidence. Curr Probl Pediatr Adolesc Health Care 2014;44:277-318.

8. Ornoy A, Weinstein-Fudim L, Ergaz Z. Prenatal factors associated with autism spectrum disorder (ASD). Reprod Toxicol 2015;56:155-69.

9. Roelens S, Beck V, Aerts G, Clerens S, Vanden Bergh G, Arckens L, et al. Neurotoxicity of polychlorinated biphenyls (PCBs) by disturbance of thyroid hormone-regulated genes. Ann NY Acad Sci 2005;1040:454-6.

10. Nowack N, Wittsiepe J, Kasper-Sonnenberg M, Wilhelm M, Schölmerich A. Influence of low-level prenatal exposure to PCDD/Fs and PCBs on empathizing, systemizing and autistic traits: results from the Duisburg birth cohort study. PloS One 2015;10:e0129906.

11. Kimura-Kuroda J, Nagata I, Kuroda Y. Disrupting effects of hydroxypolychlorinated biphenyl (PCB) congeners on neuronal development of cerebellar Purkinje cells: a possible causal factor for developmental brain disorders? Chemosphere 2007;67:S412-20.

12. Jacobson JL, Jacobson SW. Intellectual impairment in children exposed to polychlorinated biphenyls in utero. NEngl J Med 1996;335:783-9.

13. Braun JM, Muckle G, Arbuckle T, Bouchard MF, Fraser WD, Ouellet E, et al. Associations of prenatal urinary bisphenol A concentrations with child behaviors and cognitive abilities. Environ Health Perspect 2017; 125:067008.

14. Lee I, Eriksson P, Fredriksson A, Buratovic S, Viberg H. Developmental neurotoxic effects of two pesticides: behavior and neuroprotein studies on endosulfan and cypermethrin. Toxicol 2015;335:1-10.

15. Gunier RB, Bradman A, Harley KG, Kogut K, Eskenazi B. Prenatal residential proximity to agricultural pesticide use and IQ in 7-year-old children. Environ Health Perspect 2017;125:057002.

16. Horton MK, Rundle A, Camann DE, Barr DB, Rauh VA, Whyatt RM. Impact of prenatal exposure to piperonyl butoxide and permethrin on 36-month neurodevelopment. Pediatr 2011;127:e699-706.

17. Rauh V, Arunajadai S, Horton M, Perera F, Hoepner L, Barr DB, et al. Seven-year neurodevelopmental scores and prenatal exposure to chlorpyrifos, a common agricultural pesticide. Environ Health Perspect 2011;119:1196-201.

18. Grandjean P, Landrigan PJ. Neurobehavioural effects of developmental toxicity. Lancet Neurol 2014;13:330-8.

19. Wells GA, Shea B, O'Connell D, Peterson J, Welch V, Losos M, et al. The Newcastle-Ottawa Scale (NOS) for assessing the quality of nonrandomised studies in meta-analyses Ontario: Ottawa Hospital Research Institute; 2009 [cited 2014 Mar 25]. Available from: http://www.ohri.ca/ programs/clinical epidemiology/oxford.asp.

20. Moher D, Liberati A, Tetzlaff J, Altman DG. Preferred reporting items for systematic reviews and meta-analyses: the PRISMA statement. Ann Intern Med 2009;151:264-9.

21. Hicks SD, Wang M, Fry K, Doraiswamy V, Wohlford EM. Neurodevelopmental delay diagnosis rates are increased in a region with aerial pesticide application. Front Pediatr 2017;5:116.

22. Cheslack-Postava K, Rantakokko PV, Hinkka-Yli-Salomaki S, Surcel HM, McKeague IW, Kiviranta HA, et al. Maternal serum persistent organic pollutants in the Finnish Prenatal Study of Autism: a pilot study. Neurotoxicol Teratol 2013;38:1-5.

23. Christian MA, Samms-Vaughan M, Lee M, Bressler J, Hessabi M, Grove ML, et al. Maternal exposures associated with autism spectrum disorder in Jamaican children. J Autism Dev Disord 2018;48:2766-78.

24. Keil AP, Daniels JL, Hertz-Picciotto I. Autism spectrum disorder, flea 
and tick medication, and adjustments for exposure misclassification: the CHARGE (CHildhood Autism Risks from Genetics and Environment) case-control study. Environ Health 2014;13:3.

25. Lyall K, Croen LA, Sjodin A, Yoshida CK, Zerbo O, Kharrazi M, et al. Polychlorinated biphenyl and organochlorine pesticide concentrations in maternal mid-pregnancy serum samples: association with autism spectrum disorder and intellectual disability. Environ Health Perspect 2017;125:474-80.

26. Mitchell MM, Woods R, Chi LH, Schmidt RJ, Pessah IN, Kostyniak PJ, et al. Levels of select PCB and PBDE congeners in human postmortem brain reveal possible environmental involvement in 15q11-q13 duplication autism spectrum disorder. Environ Mol Mutagen 2012;53:589-98.

27. Roberts EM, English PB, Grether JK, Windham GC, Somberg L, Wolff C. Maternal residence near agricultural pesticide applications and autism spectrum disorders among children in the California Central Valley. Environ Health Perspect 2007;115:1482-9.

28. von Ehrenstein OS, Ling C, Cui X, Cockburn M, Park AS, Yu F, et al. Prenatal and infant exposure to ambient pesticides and autism spectrum disorder in children: population based case-control study. BMJ 2019;364: 1962.

29. Bernardo BA, Lanphear BP, Venners SA, Arbuckle TE, Braun JM, Muckle $\mathrm{G}$, et al. Assessing the relation between plasma PCB concentrations and elevated autistic behaviours using bayesian predictive odds ratios. Int J Environ Res Public Health 2019;16:457.

30. Brown AS, Cheslack-Postava K, Rantakokko P, Kiviranta H, Hinkka-YliSalomaki S, McKeague IW, et al. Association of maternal insecticide levels with autism in offspring from a national birth cohort. Am J Psychiatry 2018;175:1094-101.

31. Granillo L, Sethi S, Keil KP, Lin Y, Ozonoff S, Iosif AM, et al. Polychlorinated biphenyls influence on autism spectrum disorder risk in the MARBLES cohort. Int J Environ Res Public Health 2019;171:177-84.

32. Philippat C, Barkoski J, Tancredi DJ, Elms B, Barr DB, Ozonoff S, et al. Prenatal exposure to organophosphate pesticides and risk of autism spectrum disorders and other non-typical development at 3 years in a high-risk cohort. Mol Autism 2018;221:548-55.

33. Yu GW, Laseter J, Mylander C. Persistent organic pollutants in serum and several different fat compartments in humans. J Environ Public Health 2011;2011:417980.

34. Kim YS, Leventhal BL, Koh YJ, Fombonne E, Laska E, Lim EC, et al. Prevalence of autism spectrum disorders in a total population sample. Am
J Psych 2011;168:904-12

35. Lee DH, Jacobs DR Jr, Porta M. Hypothesis: a unifying mechanism for nutrition and chemicals as lifelong modulators of DNA hypomethylation. Environ Health Perspect 2009;117:1799-802.

36. Lyall K, Croen LA, Sjödin A, Yoshida CK, Zerbo O, Kharrazi M, et al. Polychlorinated biphenyl and organochlorine pesticide concentrations in maternal mid-pregnancy serum samples: association with autism spectrum disorder and intellectual disability. Environ Health Perspect 2016;125:474-80.

37. Furlong MA, Engel SM, Barr DB, Wolff MS. Prenatal exposure to organophosphate pesticides and reciprocal social behavior in childhood. Environ Intr 2014;70:125-31.

38. De Felice A, Greco A, Calamandrei G, Minghetti L. Prenatal exposure to the organophosphate insecticide chlorpyrifos enhances brain oxidative stress and prostaglandin E 2 synthesis in a mouse model of idiopathic autism. J Neuroinflamm 2016;13:149.

39. Sagiv SK, Harris MH, Gunier RB, Kogut KR, Harley KG, Deardorff J, et al. Prenatal organophosphate pesticide exposure and traits related to autism spectrum disorders in a population living in proximity to agriculture. Environ Health Perspect 2018;126:047012.

40. Herzine A, Laugeray A, Feat J, Menuet A, Quesniaux V, Richard O, et al. Perinatal eposure to glufosinate ammonium herbicide impairs neurogenesis and neuroblast migration through cytoskeleton destabilization. Front Cell Neurosci 2016;10:191.

41. Mullen BR, Khialeeva E, Hoffman DB, Ghiani CA, Carpenter EM. Decreased reelin expression and organophosphate pesticide exposure alters mouse behaviour and brain morphology. ASN Neuro 2012;5: e00106.

42. Laugeray A, Herzine A, Perche O, Hébert B, Aguillon-Naury M, Richard $\mathrm{O}$, et al. Pre-and postnatal exposure to low dose glufosinate ammonium induces autism-like phenotypes in mice. Front Behav Neurosci 2014;8: 390.

How to cite this article: Mehri F, Bashirian S, Khazaei S, Jenabi E. Association between pesticide and polychlorinated biphenyl exposure during pregnancy and autism spectrum disorder among children: a meta-analysis. Clin Exp Pediatr 2021;64:28692. https://doi.org/10.3345/cep.2020.00864 